Article

\title{
Mononuclear Nickel(II) Complexes with Schiff Base Ligands: Synthesis, Characterization, and Catalytic Activity in Norbornene Polymerization
}

\author{
Yi-Mei Xu, Kuan Li, Yuhong Wang, Wei Deng * and Zi-Jian Yao * \\ School of Chemical and Environmental Engineering, Shanghai Institute of Technology, Shanghai 201418, China; \\ 166061228@sit.edu.cn (Y.-M.X.); 156061209@sit.edu.cn (K.L.); yuhong_wang502@sit.edu.cn (Y.W.) \\ * Correspondence: wdeng@sit.edu.cn (W.D.); zjyao@sit.edu.cn (Z.-J.Y.); \\ Tel.: +86-21-6087-7231 (Z.-J.Y.); Fax: +86-21-6087-3335 (Z.-J.Y.)
}

Academic Editor: Marinos Pitsikalis

Received: 23 February 2017; Accepted: 13 March 2017; Published: 16 March 2017

\begin{abstract}
The nickel(II) catalyst has manifested higher catalytic activity compared to that of other late transition metal catalysts for norbornene polymerization. Therefore, several structurally similar trans-nickel(II) compounds of $\mathrm{N}, \mathrm{O}$-chelate bidentate ligands were synthesized and characterized. Both the electronic effect and the steric hindrance influence polymerization. The molecular structures of 2, 4 and 5 were further confirmed by single-crystal X-ray diffraction.
\end{abstract}

Keywords: Schiff base; X-ray crystals; catalysis; polymerization; nickel(II) complex

\section{Introduction}

Over the past two decades, polynorbornene (PNB) has been widely utilized in industrial production because of its excellent physical and chemical properties, including its high solubility in ordinary organic solvents, its excellent heat resistivity, and its optical transparency [1-4]. There are three pathways for norbornene polymerziation (Scheme 1): (i) Ring-opening metathesis polymerization (ROMP). The obtained product still contains double bonds in the backbone of polynorbornene [5]. (ii) Cationic or radical polymerization. Polynorbornenes synthesized by this route often show low molecular weights [6]. (iii) Vinyl-type polymerization. The bicyclic motifs remain in the polymer chain of the polynorbornene given via this polymerization route [7]. It was obtained first by using a $\mathrm{TiCl}_{4}$-based Ziegler catalyst, but these and subsequent zirconocene/MAO catalytic systems perform with lower activities [8-10]. The products (PNB) displays a characteristically rigid random coil conformation, which shows a restricted rotation around the main chain and exhibits high thermal stability $\left(T_{\mathrm{g}}>350{ }^{\circ} \mathrm{C}\right)$.
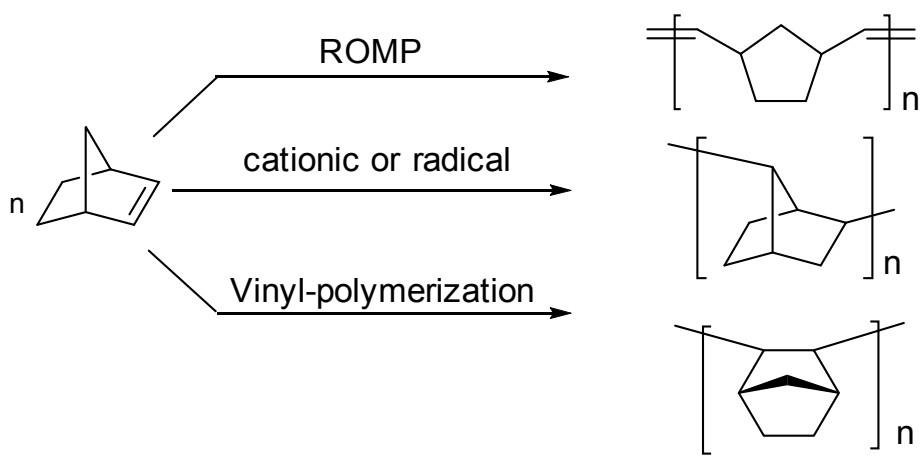

Scheme 1. Three different types of polymerization for norbornene. 
Under the stimulation of academic and commercial factors, different transition metal complexes based on various ligands, such as bidentate ligands $\mathrm{N}^{\wedge} \mathrm{N}$ [11,12], $\mathrm{N}^{\wedge} \mathrm{O}$ [13-17], $\mathrm{N}^{\wedge} \mathrm{P}$ [18], and $\mathrm{P}^{\wedge} \mathrm{P}$ [19] and tridentate ligands $\mathrm{N}^{\wedge} \mathrm{N}^{\wedge} \mathrm{N}$ [20], $\mathrm{N}^{\wedge} \mathrm{N}^{\wedge} \mathrm{O}$ [21], and $\mathrm{N}^{\wedge} \mathrm{P}^{\wedge} \mathrm{N}$ [22], were designed and prepared for olefin polymerization. Among these metal complexes, Ni-based catalysts are best known to oligomerize ethylene and dimerize propylene and higher R-olefins because, before 1995, nickel(II) metal was generally thought to prefer $\alpha$-hydride elimination followed by reductive elimination [23-26]. However, transition-metal complexes with ligands containing dissimilar donor atoms have been widely studied, primarily for their applications in important homogeneous catalytic processes [27-29]. In particular, the complexes bearing bidentate $\mathrm{N}^{\wedge} \mathrm{O}$ ligands have drawn more attention than ever before. Additionally, on the basis of previous reports, nickel(II) complexes with $\mathrm{N}^{\wedge} \mathrm{O}$ ligands often exhibited good catalytic activity for olefin polymerization [13-15].

We are always interested in studying novel intramolecularly coordinated nickel(II) complexes with polymerization activity. Here, a series of mononuclear nickel(II) complexes based on the bis- $\mathrm{N}^{\wedge} \mathrm{O}-$ chelate ligand was designed and synthesized so that their polymerization activity could be investigated. These complexes exhibited catalytic activity that is good for the polymerization of norbornene in the presence of methylaluminoxane (MAO) as a co-catalyst. Moreover, the effects that influenced catalytic behavior are herein discussed.

\section{Results and Discussion}

\subsection{Synthesis of $N, O$ Bidentate Ligands HL1-HL5}

According to previous methods [30-32], the bidentate ligands HL1-HL5 were obtained in high yields by the reaction between 2-hydroxy-1-naphthaldehyde and corresponding aryl amines in ethanol solutions. They were isolated as yellow solids in high yields (Scheme 2). The ${ }^{1} \mathrm{H}-\mathrm{NMR}$ spectra and elemental analysis data all ascertain the identity of the ligands.

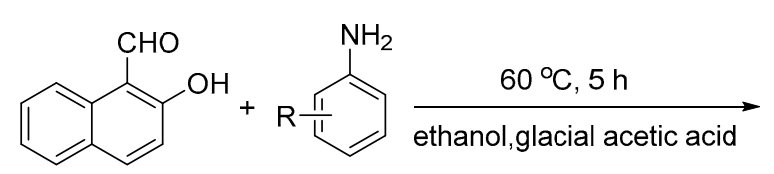

ethanol,glacial acetic acid

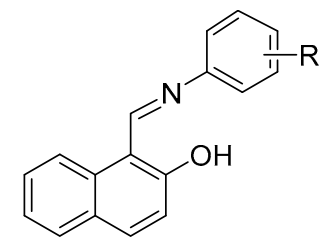

HL1-HL5

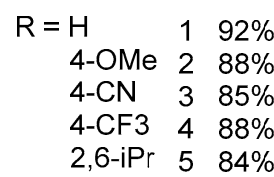

$2,6-\mathrm{iPr} 5 \quad 84 \%$

Scheme 2. Synthesis of N,O-chelate bidentate ligands HL1-HL5.

\subsection{Synthesis of $\mathrm{N}, \mathrm{O}$-Coordinate Ni(II) Complexes $\mathbf{1 - 5}$}

Analogous to the procedure of preparing copper(II) complexes [13-15], the reactions of Schiff base ligands HL1-HL5 with nickel(II) acetate yielded the $\mathrm{N}, \mathrm{O}$-chelate $\mathrm{Ni}(\mathrm{II})$ Complexes $\mathbf{1 - \mathbf { 5 }}$ in good yields (Scheme 3). The products precipitated from the solution after the reaction was cooled to room temperature. Complexes 1-5 are soluble in toluene and dichloromethane but slightly soluble in diethyl ether and petroleum ether. They are stable at room temperature in air. No decomposition was observed even after refluxing in toluene for several hours. HRMS spectra of complexes 1-5 have exhibited strong molecular peaks (Figures S1-S5). Meanwhile, TGA characterization confirmed their thermal stability (Figure S6). However, the ${ }^{1} \mathrm{H}$ and ${ }^{13} \mathrm{C}-\mathrm{NMR}$ spectra of these complexes are not informative because of the para-magnetism of the nickel(II) complexes. The IR spectra of $\mathrm{N}, \mathrm{O}$-chelate $\mathrm{Ni}$ (II) complexes are similar to each other. The common feature of these complexes is that the $\mathrm{C}=\mathrm{N}$ stretching vibration of the ligands $\left(1625-1635 \mathrm{~cm}^{-1}\right)$ are shifted to lower frequencies $\left(1610 \mathrm{~cm}^{-1}\right)$. 


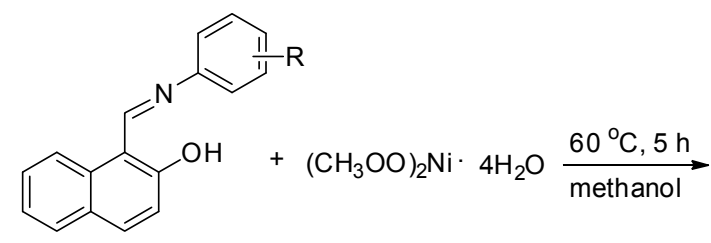

HL1-HL5

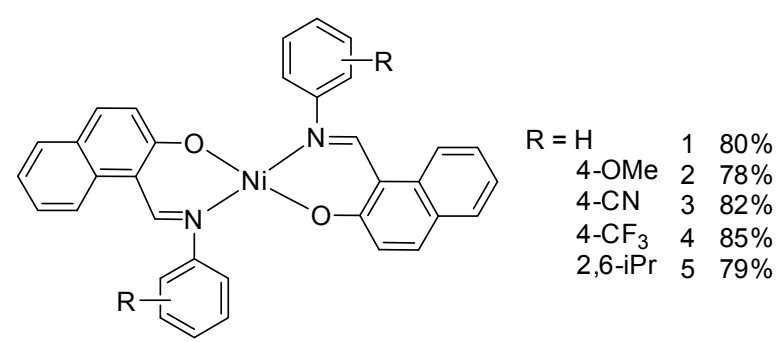

$1-5$

Scheme 3. Synthesis of N,O-coordinate Ni(II) Complexes 1-5.

\subsection{UV-Vis Spectroscopy}

Figure 1 shows the UV-Vis spectra of the nickel(II) Complexes 1-5 in dichloromethane solutions. The UV-Vis absorption spectral data is presented in Table 1. The absorption spectra of all complexes is characterized by intense absorption bands in the range of 319-324 nm, which are assigned to the $\pi \rightarrow \pi^{*}$ molecular orbitals localized on the imine group and the aromatic ring [33]. The lower-intensity absorption bands in the 366-382 $\mathrm{nm}$ region are assigned to the metal-to-ligand charge transfer (MLCT) [34]. The ultraviolet spectra measurements of these complexes demonstrate that their electronic structures are similar to each other.

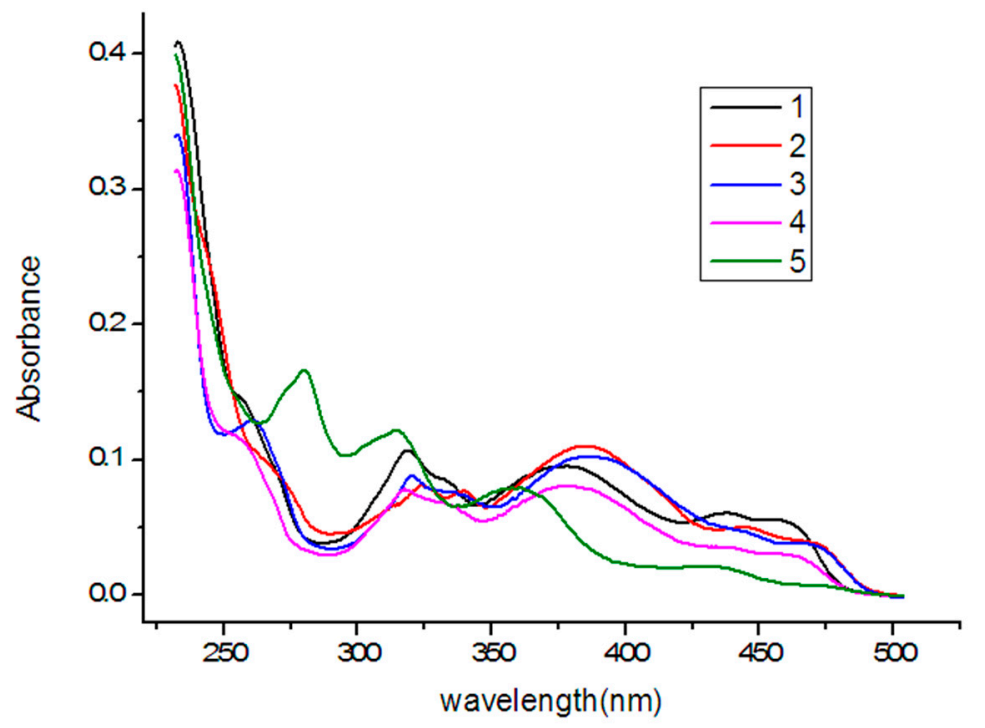

Figure 1. UV-Vis spectra of Complexes 1-5 $\left(3.59 \times 10^{-6} \mathrm{~mol} \cdot \mathrm{dm}^{-3}\right.$ in $\left.\mathrm{CH}_{2} \mathrm{Cl}_{2}\right)$.

Table 1. UV-Vis Spectra Data of Complexes 1-5 in $\mathrm{CH}_{2} \mathrm{Cl}_{2}$.

\begin{tabular}{|c|c|}
\hline Complex & $\lambda_{\mathrm{abs}} / \mathrm{nm}\left(\varepsilon / \mathrm{dm}^{3} \cdot \mathrm{mol}^{-1} \cdot \mathrm{cm}^{-1}\right)$ \\
\hline 1 & $319\left(2.97 \times 10^{4}\right) ; 378\left(2.67 \times 10^{4}\right)$ \\
\hline 2 & $324\left(2.28 \times 10^{4}\right) ; 382\left(3.06 \times 10^{4}\right)$ \\
\hline 3 & $320\left(2.45 \times 10^{4}\right) ; 382\left(2.24 \times 10^{4}\right)$ \\
\hline 4 & $319\left(2.17 \times 10^{4}\right) ; 377\left(2.26 \times 10^{4}\right)$ \\
\hline 5 & $316\left(3.40 \times 10^{4}\right) ; 366\left(2.14 \times 10^{4}\right)$ \\
\hline
\end{tabular}

\subsection{X-ray Crystallographic}

In order to identify the structures of these nickel(II) complexes, single-crystal X-ray diffraction measurement was carried out on Complexes 2, 4, and 5. Suitable crystals were obtained by slow diffusion of n-hexane into their concentrated solution of dichloromethane. Selected bond lengths and 
angles (Table S1) and their crystal data (Table S2) are listed in the supporting information. As shown in Figure 2, they have analogous structures in a solid state. Their structures are centrosymmetric with the symmetry centers located on the metal centers. Although previous reports indicated that the steric and electron effects of the substituent groups on the aromatic rings of bulky four-coordinated transition metal complexes probably distort the geometry of the metal center from the planar coordination to the pseudo-tetrahedral geometry [35-37]; however, the $\mathrm{NiN}_{2} \mathrm{O}_{2}$ chromophores of the three nickel(II) complexes are absolutely planar with the dihedral angles of 0 between the planes of $\mathrm{N}(1)-\mathrm{Ni}(1)-\mathrm{O}(1)$ and $\mathrm{N}(1 \mathrm{~A})-\mathrm{Ni}(1)-\mathrm{O}(1 \mathrm{~A})$. The $\mathrm{Ni}(1)-\mathrm{N}(1)$ and $\mathrm{Ni}(1)-\mathrm{O}(1)$ distances are both located in the range of known values for these bonds in analogous complexes [38]. The structures of the three complexes are similar to each other except for the slight differences in bond distance and angles. We failed to obtain single crystals of other nickel(II) complexes after many attempts.
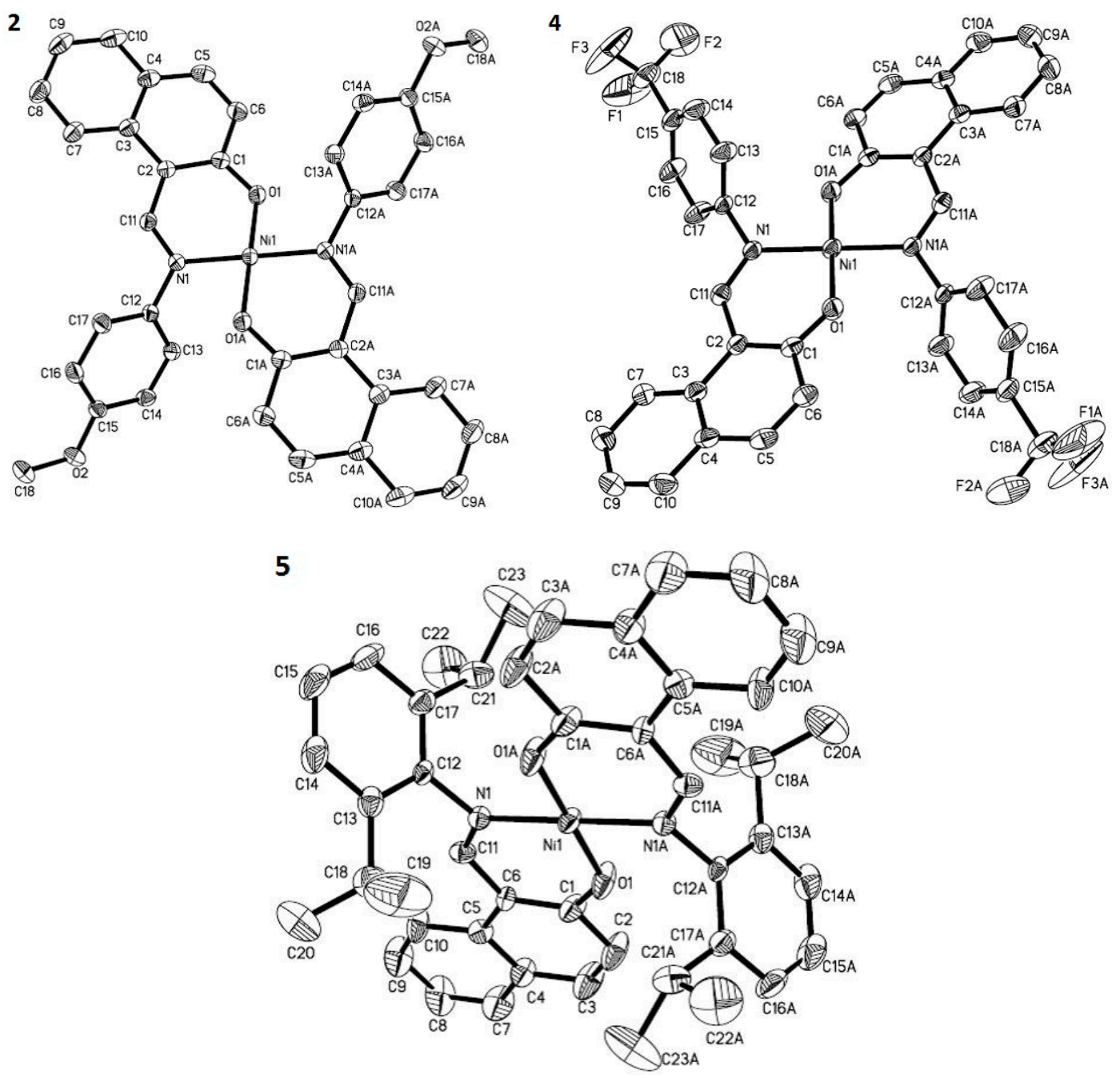

Figure 2. Molecular structures of 2, 4, and 5 with 30\% probability ellipsoids. Hydrogen atoms are omitted for clarity.

\subsection{Polymerization of Norbornene}

The catalytic behavior of these nickel(II) complexes was investigated based on our previous work [39]. Preliminary experiments on norbornene polymerization were carried out in the presence of MAO as a co-catalyst. We chose chlorobenzene as the reaction solvent for the polymerization process because the polar solvent was able to improve the catalytic performances in norbornene vinyl polymerization (Scheme 4). Experimental results are summarized in Table 2. No catalytic activity 
was observed for Complex 1 without the addition of MAO (Table 2, Entry 1). For Complex 1/MAO catalytic system, the optimal molar ratio of Al/Ni was 2500 (Table 2, Entries 6 and 8). The catalytic activity and molecular weight $\left(M_{\mathrm{W}}\right)$ of the polymer were higher in the presence of increasing amounts of MAO (Table 2, Entries 2-6). However, the catalytic activity slightly decreased when the Al/Ni ratio was increased to 3000 (Table 2, Entry 7). The catalyst performance was also influenced by the reaction temperature, and $60{ }^{\circ} \mathrm{C}$ is the best choice (Table 2, Entry 8). The decrease of catalytic activity was observed at higher temperatures $\left(90^{\circ} \mathrm{C}\right)$, probably because of the decomposition or instability of the active species formed by the catalytic precursors (Table 2, Entry 9). For Complex 4, the highest catalytic activity, up to $3.06 \times 10^{6} \mathrm{gPNB} \mathrm{mol}^{-1} \mathrm{Ni} \mathrm{h}^{-1}$, was obtained at $60^{\circ} \mathrm{C}$ in the optimal $\mathrm{Al} / \mathrm{Ni}$ molar ratio (Table 2, Entry 12). This complex showed much higher catalytic activity (almost two times) than that of the C,S-chelate nickel(II) complex based on the carborane ligand [38]. In comparison with the nickel complex(II) with N,P-ligand [7], the catalytic activity of Complex 4 is lower; however, a substantial amount of MAO should be used in the polymerization by using $N, P$-chelate nickel(II) complex as a catalyst, and the molecular weight of the obtained polynorbornenes is very low $\left(6.47 \times 10^{5} \mathrm{~g} \cdot \mathrm{mol}^{-1}\right)$. Results showed that both electronic and steric effects of the substituted groups had an influence on the catalyst performance. Generally, the transition metal complexes with an electron-withdrawing group that bonded to the ligands often showed higher catalytic activity, because the electron-withdrawing group made the metal center more electron-deficient and the olefin could easily coordinate to the metal center [39]. On the other hand, bulky substituted groups bonded to the transition metal complexes are of great benefit to the polymerization, because the bulky groups can protect the metal center and $\beta-\mathrm{H}$ elimination is inhibited in the polymerization process. For example, Complex 4 with the 4-trifluoromethyl group exhibited higher catalytic activity than that of Complexes 1, 2, 3, and 5 (Table 2, Entries 8 and 10-13). This result indicates that the electron effects play a more important role than that of the steric effects for these nickel(II) complexes.

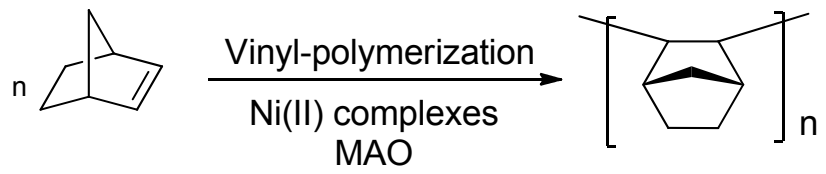

Scheme 4. Vinyl-polymerization catalyzed by Ni(II) complexes.

Table 2. Polymerization of norbornene Complexes 1-5 activated by $\mathrm{MAO}^{a}$.

\begin{tabular}{ccccccc}
\hline Entry & Catalyst & $\mathbf{A} \mathbf{l} / \mathbf{N i}$ & $\boldsymbol{T}^{\circ} \mathbf{C}$ & Yield/g & Activity & $\boldsymbol{M}_{\mathbf{v}}{ }^{\boldsymbol{c}}$ \\
\hline 1 & 1 & 0 & 30 & 0 & - & - \\
2 & 1 & 500 & 30 & 0.43 & 0.86 & 1.21 \\
3 & 1 & 1000 & 30 & 0.51 & 1.02 & 1.44 \\
4 & 1 & 1500 & 30 & 0.59 & 1.18 & 1.63 \\
5 & 1 & 2000 & 30 & 0.92 & 1.84 & 1.96 \\
6 & 1 & 2500 & 30 & 1.08 & 2.16 & 2.09 \\
7 & 1 & 3000 & 30 & 0.96 & 1.92 & 1.88 \\
8 & 1 & 2500 & 60 & 1.23 & 2.46 & 2.03 \\
9 & 1 & 2500 & 90 & 0.65 & 1.30 & 2.01 \\
10 & 2 & 2500 & 60 & 1.33 & 2.35 & 2.23 \\
11 & 3 & 2500 & 60 & 1.29 & 2.58 & 2.66 \\
12 & 4 & 2500 & 60 & 1.53 & 3.06 & 2.85 \\
13 & 5 & 2500 & 60 & 1.42 & 2.84 & 2.37 \\
\hline
\end{tabular}

a Polymerization conditions: $[\mathrm{NB}]=1.80 \mathrm{~g} ; V_{\text {total }}=10 \mathrm{~mL}$; catalyst: nickel Complexes 1-5, $1 \mu \mathrm{mol}$, reaction time: $30 \mathrm{~min}$, solvent: chlorobenzene. ${ }^{b} 10^{6} \mathrm{gPNB} \mathrm{mol}^{-1} \mathrm{Ni} \mathrm{h}^{-1} \cdot{ }^{c} 10^{6} \mathrm{~g} \cdot \mathrm{mol}^{-1}$, measured in chlorobenzene at $25^{\circ} \mathrm{C}$ using the Mark-Houwink coefficients.

The obtained polynorbornenes were characterized by IR and-NMR spectroscopy (Figure S7). The characteristic peaks of these polymers at approximately $942 \mathrm{~cm}^{-1}$ were analogous. These absorption 
peaks at about $942 \mathrm{~cm}^{-1}$ were identified to the ring system of bicycle heptane [40]. There are no absorptions at about 735 and $960 \mathrm{~cm}^{-1}$, suggesting that no ROMP structure of polynorbornenes were found, because the two absorptions are assign to the trans and cis forms of double bonds, respectively, which are characteristic of the ROMP structure of polynorbornenes [41-43]. The ${ }^{1} \mathrm{H}$ HMR polynorbornenes displayed four groups of signals in the range of $\delta 1.0-3.0 \mathrm{ppm}$. The absence of the resonances at approximately $\delta 5.1$ and $5.3 \mathrm{ppm}$ in the ${ }^{1} \mathrm{H}-\mathrm{NMR}$ spectra further confirms that the polymers are vinyl-type addition products [44].

\section{Experimental Section}

\subsection{General Data}

All experiments were carried out under an atmosphere of nitrogen using standard Schlenk techniques. Ethanol and methanol were used as commercial products without further purification. ${ }^{1} \mathrm{H}-\mathrm{NMR}(500 \mathrm{MHz})$ spectra was measured with a Bruker DMX-500 spectrometer (Bruker, Washington, DC, USA). Elemental analysis was performed on an Elementar vario EL III analyzer (Elementar, Langenselbold, Germany). UV-Vis absorption spectra were recorded using a UV 765 spectrophotometer (Shimadzu, Kyoto, Japan) with quartz cuvettes with a $1 \mathrm{~cm}$ path length. IR (KBr) spectra were measured with the Nicolet FT-IR spectrophotometer (Thermo Fisher Scientific, Waltham, MA, USA).

\subsection{Synthesis of Ligands HL1-HL5}

The Schiff base ligands HL1-HL5 were synthesized by a routine method. 2-Hydroxy-1naphthaldehyde $(5.0 \mathrm{mmol})$ and corresponding amines $(5.0 \mathrm{mmol})$ were combined and heated to reflux in ethanol for $6 \mathrm{~h}$ in the presence of catalytic amount of ethyl acetate, resulting in a color change from colorless to bright yellow. Solvent was concentrated under reduced pressure and stored at $-10{ }^{\circ} \mathrm{C}$ overnight, and further purification was achieved by filtration and washed with $\mathrm{CH}_{3} \mathrm{OH}(3 \times 10 \mathrm{~mL})$. The collected solid was dried under vacuum.

HL1: yellow solid; $1.13 \mathrm{~g}$, 92\% yield. ${ }^{1} \mathrm{H}-\mathrm{NMR}\left(500 \mathrm{MHz}, \mathrm{CDCl}_{3}, 25^{\circ} \mathrm{C}\right): \delta 15.54(\mathrm{~s}, 1 \mathrm{H}), 9.36(\mathrm{~d}, J=4.5 \mathrm{~Hz}$, $1 \mathrm{H}), 8.13(\mathrm{~d}, J=8.5 \mathrm{~Hz}, 1 \mathrm{H}), 7.83(\mathrm{~d}, J=9.5 \mathrm{~Hz}, 1 \mathrm{H}), 7.74(\mathrm{~d}, J=8.0 \mathrm{~Hz}, 1 \mathrm{H}), 7.56(\mathrm{t}, J=9.0 \mathrm{~Hz}, 1 \mathrm{H}), 7.51$ $(\mathrm{t}, J=9.0 \mathrm{~Hz}, 2 \mathrm{H}), 7.41-7.30$ (m, 5H). IR (KBr, disk): $v 3066,1621,1568,1488,1331,821,750,695 \mathrm{~cm}^{-1}$. Elemental analysis calcd (\%) for $\mathrm{C}_{17} \mathrm{H}_{13} \mathrm{NO}$ : C 82.57, H 5.30, N 5.66, found: C 82.68, H 5.35, N 5.47.

HL2: yellow solid; $1.22 \mathrm{~g}$, $88 \%$ yield. ${ }^{1} \mathrm{H}-\mathrm{NMR}\left(500 \mathrm{MHz}, \mathrm{CDCl}_{3}, 25^{\circ} \mathrm{C}\right): \delta 15.71(\mathrm{~s}, 1 \mathrm{H}), 9.35(\mathrm{~d}, J=4.0 \mathrm{~Hz}$, $1 \mathrm{H}), 8.14(\mathrm{~d}, J=8.5 \mathrm{~Hz}, 1 \mathrm{H}), 7.82(\mathrm{~d}, J=9.0 \mathrm{~Hz}, 1 \mathrm{H}), 7.75(\mathrm{~d}, J=8.0 \mathrm{~Hz}, 1 \mathrm{H}), 7.56(\mathrm{t}, J=9.6 \mathrm{~Hz}, 1 \mathrm{H})$, $7.38-7.34(\mathrm{~m}, 3 \mathrm{H}), 7.14(\mathrm{~d}, J=9.0 \mathrm{~Hz}, 1 \mathrm{H}), 7.02(\mathrm{~d}, J=9.0 \mathrm{~Hz}, 2 \mathrm{H}), 3.88(\mathrm{~s}, 3 \mathrm{H}) . \mathrm{IR}(\mathrm{KBr}$, disk): $v 3051$, $1621,1507,1302,1252,821,750,502 \mathrm{~cm}^{-1}$. Elemental analysis calcd (\%) for $\mathrm{C}_{18} \mathrm{H}_{15} \mathrm{NO}_{2}$ : C 77.96, $\mathrm{H} 5.45$, N 5.05, found: C 77.79, H 5.38, N 5.23.

HL3: yellow solid; $1.41 \mathrm{~g}, 85 \%$ yield. ${ }^{1} \mathrm{H}-\mathrm{NMR}\left(500 \mathrm{MHz}, \mathrm{CDCl}_{3}, 25^{\circ} \mathrm{C}\right): \delta 15.23(\mathrm{~s}, 1 \mathrm{H}), 9.08(\mathrm{~d}, J=3.0 \mathrm{~Hz}$, $1 \mathrm{H}), 8.00(\mathrm{~d}, J=8.5 \mathrm{~Hz}, 1 \mathrm{H}), 7.88(\mathrm{~d}, J=9.0 \mathrm{~Hz}, 1 \mathrm{H}), 7.78(\mathrm{~d}, J=8.0 \mathrm{~Hz}, 1 \mathrm{H}), 7.52(\mathrm{t}, J=8.0 \mathrm{~Hz}, 1 \mathrm{H})$, $7.37(\mathrm{t}, J=7.5 \mathrm{~Hz}, 1 \mathrm{H}), 7.26-7.25(\mathrm{~m}, 3 \mathrm{H}), 7.21(\mathrm{~d}, J=9.5 \mathrm{~Hz}, 1 \mathrm{H}), 3.16-3.07(\mathrm{~m}, 2 \mathrm{H}), 1.24(\mathrm{~d}, J=7.0 \mathrm{~Hz}$, 12H). IR (KBr, disk): $v 3062,1624,1463,1330,1246,824,796,747 \mathrm{~cm}^{-1}$. Elemental analysis calcd (\%) for $\mathrm{C}_{23} \mathrm{H}_{25} \mathrm{NO}: \mathrm{C}$ 83.34, H 7.60, N 4.23, found: C 83.39, H 7.53, N 4.36.

HL4: yellow solid; $1.38 \mathrm{~g}, 88 \%$ yield. ${ }^{1} \mathrm{H}-\mathrm{NMR}\left(500 \mathrm{MHz}, \mathrm{CDCl}_{3}, 25^{\circ} \mathrm{C}\right): \delta 15.12(\mathrm{~s}, 1 \mathrm{H}), 9.40(\mathrm{~d}, J=2.5 \mathrm{~Hz}$, $1 \mathrm{H}), 8.15(\mathrm{~d}, J=8.5 \mathrm{~Hz}, 1 \mathrm{H}), 7.88(\mathrm{~d}, J=9.5 \mathrm{~Hz}, 1 \mathrm{H}), 7.76-7.73(\mathrm{~m}, 3 \mathrm{H}), 7.59(\mathrm{t}, J=7.5 \mathrm{~Hz}, 1 \mathrm{H}), 7.46(\mathrm{~d}$, $J=8.5 \mathrm{~Hz}, 2 \mathrm{H}), 7.41(\mathrm{t}, J=7.5 \mathrm{~Hz}, 1 \mathrm{H}), 7.15(\mathrm{~d}, J=9.0 \mathrm{~Hz}, 1 \mathrm{H}) . \mathrm{IR}(\mathrm{KBr}$, disk $): v 3057,1627,1584,1320$, $1156,753,595 \mathrm{~cm}^{-1}$. Elemental analysis calcd (\%) for $\mathrm{C}_{18} \mathrm{H}_{12} \mathrm{~F}_{3} \mathrm{NO}$ : C 68.57, H 3.84, N 4.44, found: C 68.63, H 3.85, N 4.55.

HL5: yellow solid; $1.14 \mathrm{~g}$, 84\% yield. ${ }^{1} \mathrm{H}-\mathrm{NMR}\left(500 \mathrm{MHz}, \mathrm{CDCl}_{3}, 25^{\circ} \mathrm{C}\right): \delta 14.94(\mathrm{~s}, 1 \mathrm{H}), 9.40(\mathrm{~d}, J=3.0 \mathrm{~Hz}$, $1 \mathrm{H}), 8.15(\mathrm{~d}, J=8.5 \mathrm{~Hz}, 1 \mathrm{H}), 7.90(\mathrm{~d}, J=9.5 \mathrm{~Hz}, 1 \mathrm{H}), 7.79(\mathrm{~d}, J=8.5 \mathrm{~Hz}, 3 \mathrm{H}), 7.60(\mathrm{t}, J=7.5 \mathrm{~Hz}, 1 \mathrm{H})$, 
7.46-7.40 (m, 3H), $7.16(\mathrm{~d}, J=9.0 \mathrm{~Hz}, 1 \mathrm{H}) . \mathrm{IR}(\mathrm{KBr}$, disk): v 3060, 1624, 1586, 1308, 1156, 953, 829, $754 \mathrm{~cm}^{-1}$. Elemental analysis calcd (\%) for $\mathrm{C}_{18} \mathrm{H}_{12} \mathrm{~N}_{2} \mathrm{O}: \mathrm{C} 79.39, \mathrm{H} 4.44, \mathrm{~N} 10.29$, found: C 79.45, H 4.49, N 10.18 .

\subsection{Synthesis of Nickel(II) Complexes 1-5}

A mixture of acetic acid nickel(II) salt $\mathrm{Ni}(\mathrm{OAc})_{2} \cdot \mathrm{H}_{2} \mathrm{O}(0.15 \mathrm{mmol})$ and methanol $(10 \mathrm{~mL})$ was added to the solution of the ligands HL1-HL5 $(0.3 \mathrm{mmol})$ in methanol $(10 \mathrm{~mL})$ [15]. After stirring at $60{ }^{\circ} \mathrm{C}$ for $5 \mathrm{~h}$, the deep green solid was collected by filtration and washed with methanol for several times.

1: deep green soild; $595 \mathrm{mg}$, 72\% yield. IR (KBr, disk): $v$ 1612, 1574., 1530, 751.71, $697 \mathrm{~cm}^{-1}$. Elemental analysis calcd (\%) for $\mathrm{C}_{34} \mathrm{H}_{24} \mathrm{~N}_{2} \mathrm{NiO}_{2}$ : C 74.08, $\mathrm{H}$ 4.39, N 5.08; Found: C 74.00, H 4.37, N 5.11. ESI-HRMS: $m / z$ calcd for $\mathrm{C}_{34} \mathrm{H}_{24} \mathrm{~N}_{2} \mathrm{NiO}_{2}[\mathrm{M}+\mathrm{H}]^{+}$: 551.1270; Found: 551.1261.

2 deep green soild; $713 \mathrm{mg}$, 78\% yield. IR (KBr, disk): $v$ 1615, 1598, 1536, 1500, 1356, 1238, 1185, 822, $748 \mathrm{~cm}^{-1}$. Elemental analysis calcd (\%) for $\mathrm{C}_{36} \mathrm{H}_{28} \mathrm{~N}_{2} \mathrm{NiO}_{4}$ : C 70.73, $\mathrm{H} 4.62, \mathrm{~N} 4.58$; Found: $\mathrm{C} 70.79$, $\mathrm{H}$ 4.52, N 4.57. ESI-HRMS: $m / z$ calcd for $\mathrm{C}_{36} \mathrm{H}_{28} \mathrm{~N}_{2} \mathrm{NiO}_{4}[\mathrm{M}+\mathrm{H}]^{+}$: 611.1481; Found: 611.1495.

3: brown soild; $612 \mathrm{mg}$, 68\% yield. IR (KBr, disk): $v$ 1598, 1530, 1497, 1433, 1364, 1190, 827, $746 \mathrm{~cm}^{-1}$. Elemental analysis calcd (\%) for $\mathrm{C}_{36} \mathrm{H}_{22} \mathrm{~N}_{4} \mathrm{NiO}_{2}$ : C 71.91, H 3.69, N 9.32; Found: C 71.96, H 3.67, N 9.31. ESI-HRMS: $m / z$ calcd for $\mathrm{C}_{36} \mathrm{H}_{22} \mathrm{~N}_{4} \mathrm{NiO}_{2}[\mathrm{M}+\mathrm{H}]^{+}$: 601.1174; Found: 601.1172 .

4: brown soild; $761 \mathrm{mg}$, 74\% yield. IR (KBr, disk): $v$ 1616, 1602, 1580, 1536, 1454., 1326, 1123, 832, $747 \mathrm{~cm}^{-1}$. Elemental analysis calcd (\%) for $\mathrm{C}_{36} \mathrm{H}_{22} \mathrm{~F}_{6} \mathrm{~N}_{2} \mathrm{NiO}_{2}$ : C 62.92, H 3.23, N 4.08; Found: $\mathrm{C} 62.96$, H 3.27, N 4.02. ESI-HRMS: $m / z$ calcd for $\mathrm{C}_{36} \mathrm{H}_{22} \mathrm{~F}_{6} \mathrm{~N}_{2} \mathrm{NiO}_{2}[\mathrm{M}+\mathrm{H}]^{+}$: 687.1017; Found: 687.1030.

5: brown soild; $776 \mathrm{mg}, 72 \%$ yield. IR (KBr, disk): $v$ 1615, 1603, 1580, 1537, 1364, 827, $741 \mathrm{~cm}^{-1}$. Elemental analysis calcd (\%) for $\mathrm{C}_{46} \mathrm{H}_{48} \mathrm{~N}_{2} \mathrm{NiO}_{2}$ : C 76.78, H 6.72, N 3.89; Found: C 76.78, H 6.77, N 3.86. ESI-HRMS: $m / z$ calcd for $\mathrm{C}_{46} \mathrm{H}_{48} \mathrm{~N}_{2} \mathrm{NiO}_{2}[\mathrm{M}+\mathrm{H}]^{+}$: 719.3148; Found: 719.3135 .

\subsection{Norbornene Polymerization}

In a typical procedure, $1 \mu \mathrm{mol}$ of nickel(II) Complex 1 in $1.0 \mathrm{~mL}$ of chlorobenzene, $1.80 \mathrm{~g}$ of norbornene in $3 \mathrm{~mL}$ of chlorobenzene and $6 \mathrm{~mL}$ of fresh chlorobenzene were added to a special polymerization bottle $(50 \mathrm{~mL})$ under a nitrogen atmosphere. After stirring at $30^{\circ} \mathrm{C}$ for $10 \mathrm{~min}$, a certain amount of MAO was charged into the polymerization system via a syringe and the reaction was started. After $30 \mathrm{~min}$, acidic ethanol $\left(V_{\text {ethanol }}: V_{\text {conc.HCl }}=20: 1\right)$ was added to terminate the reaction. The PNB was isolated by filtration, washed with ethanol, and dried at $80^{\circ} \mathrm{C}$ for $24 \mathrm{~h}$ under vacuum. For all polymerization procedures, the total reaction volume was $10.0 \mathrm{~mL}$, which could be achieved by varying the amount of chlorobenzene when necessary. The viscosity average molar masses $\left(M_{v}\right)$ of the PNB were obtained in chlorobenzene at $25^{\circ} \mathrm{C}$ using Mark-Houwink coefficients.

\subsection{X-ray Crystallography}

Data of 2, 4, and 5 were collected on a Bruker Smart APEX CCD diffractometer with graphite-monochromated MoK $\alpha$ radiation $(\lambda=0.71073 \AA)$. All data were collected at room temperature, and the structures were solved by direct methods and subsequently refined on $F^{2}$ by using full-matrix least-squares techniques (SHELXL) [45]. SADABS [46] absorption corrections were applied to the data, all non-hydrogen atoms were refined anisotropically, and hydrogen atoms were located at calculated positions. All calculations were performed using the Bruker program Smart.

\section{Conclusions}

In this report, a series of $\mathrm{N}, \mathrm{O}$-chelate Schiff base $\mathrm{Ni}$ (II) complexes containing 2-hydroxy-1naphthaldehyde ligands was synthesized and characterized by IR spectra, UV, ${ }^{1} \mathrm{H}-\mathrm{NMR}$, and single-crystal X-ray diffraction analysis. Structural analysis of 2, 4, and 5 confirms that the nickel(II) 
atom coordinates with two ligands. The results of this experiment demonstrate that these nickel(II) complexes have extremely high catalytic activity $\left(3.06 \times 10^{6} \mathrm{gPNB} \mathrm{mol}^{-1} \mathrm{Ni} \mathrm{h}^{-1}\right)$ for norbornene polymerization when using MAO as a co-catalyst. The utilization of these nickel(II) complexes as catalysts in the oxidation of olefins is currently underway in our laboratory.

Supplementary Materials: The following are available online at www.mdpi.com/2073-4360/9/3/105/s1, Figure S1: HRMS of complex 1. Figure S2: HRMS of complex 2. Figure S3: HRMS of complex 3. Figure S4: HRMS of complex 4. Figure S5: HRMS of complex 5. Figure S6: TGA curves of complexes 1-5. Figure S7: IR spectrum and ${ }^{1} \mathrm{H}$ NMR spectrum of PNB. Table S1: Selected Bond Lengths ( $\AA$ ) and Angles (०) for Complexes 2, 4, and 5. Table S2: Crystal data for Complexes 2, 4, and 5.

Acknowledgments: This work was supported by the National Natural Science Foundation of China (No. 21601125), the Chenguang Scholar of Shanghai Municipal Education Commission, Natural Science Foundation of Shanghai (No. 16ZR1435700), Local Institutions Capacity Training of Shanghai Science and Technology Commission, the Shanghai Municipal Education Commission (Plateau Discipline Construction Program), and the Start Funding of Shanghai Institute of Technology (YJ2016-10).

Author Contributions: Yi-Mei Xu and Kuan Li contributed equally to this paper, Yuhong Wang, Wei Deng, and Zi-Jian Yao guided the experiment and revised the paper.

Conflicts of Interest: The authors declare no conflict of interest.

\section{Abbreviations}

PNB polynorbornenes

MAO methylaluminoxane

\section{References}

1. Janiak, C.; Lassahn, P.G. Metal catalysts for the vinyl Polymerization of norbornene. J. Mol. Catal. A Chem. 2001, 166, 193-209. [CrossRef]

2. Janiak, C.; Lassahn, P.G. The Vinyl Homopolymerization of Norbornene. Macromol. Rapid Commun. 2001, 22, 479-493. [CrossRef]

3. Grove, N.R.; Kohl, P.A.; Allen, S.A.B.; Jayaraman, S.; Shick, R. Functionalized polynorbornene dielectric polymers: Adhesion and mechanical properties. J. Polym. Sci. B Polym. Phys. 1999, 37, 3003-3010. [CrossRef]

4. Lee, D.; Choi, M.C.; Ha, C.S. Polynorbornene dicarboximide/amine functionalized graphene hybrids for potential oxygen barrier films. J. Polym. Sci. Part A Polym. Chem. 2012, 50, 1611-1621. [CrossRef]

5. Ivin, K.J.; Mol, J.C. Olefin Metathesis and Metathesis Polymerization; Academic Press: San Diego, CA, USA, 1997.

6. Chen, Z.; Trudell, M.L. Chemistry of 7-Azabicyclo[2.2.1]hepta-2,5-dienes, 7-Azabicyclo [2.2.1]hept-2-enes, and 7-Azabicyclo [2.2.1]heptanes. Chem. Rev. 1996, 96, 1179-1194. [CrossRef] [PubMed]

7. Mast, C.; Krieger, M.; Dehnicke, K.; Greiner, A. Vinyl-type polymerization of norbornene by a nickel-based catalyst with phosphoraneiminato ligands. Macromol. Rapid Commun. 1999, 20, 232-235. [CrossRef]

8. Tlenkopatchev, M.; Fomine, S.; Miranda, E.; Fomina, L.; Ogawa, T. Synthesis of Polynorbornene Containing Fluorescein Moiety. Polym. J. 1995, 27, 1173-1179. [CrossRef]

9. Kaminsky, W.; Bark, A.; Arndt, M. New polymers by homogenous zirconocene/aluminoxane catalysts. Makromol. Chem. Macromol. Symp. 1991, 47, 83-93. [CrossRef]

10. Kaminsky, W.; Noll, A. Copolymerization of norbornene and ethene with homogenous zirconocenes/ methylaluminoxane catalysts. Polym. Bull. 1993, 31, 175-182. [CrossRef]

11. Johnson, L.K.; Brookhart, S.M. Copolymerization of Ethylene and Propylene with Functionalized Vinyl Monomers by Palladium(II) Catalysts. J. Am. Chem. Soc. 1996, 118, 267-268. [CrossRef]

12. Avent, A.G.; Hitchcock, P.B.; Lappert, M.F.; Sablong, R.; Severn, J.R. Synthesis, Structures, Characterization, Dynamic Behavior, and Reactions of Novel Late Transition Metal(II) 1-Azaallyls. Organometallics 2004, 23, 2591-2600. [CrossRef]

13. Yao, Z.-J.; Li, K.; Zhang, J.-Y.; Wang, Y.; Deng, W. Synthesis, Characterization and Polymerization Activity of Copper Complexes with N, O-Chelate Ligands. Inorg. Chim. Acta 2016, 450, 118-123. [CrossRef]

14. Wang, X.; Jin, G.-X. Preparation, Structure, and Olefin Polymerization Behavior of a Picolyl-Functionalized Carborane Nickel(II) Complex. Organometallics 2004, 23, 6319-6322. [CrossRef] 
15. Meng, X.; Tang, G.-R.; Jin, G.-X. Vinyl and ring-opening metathesis polymerization of norbornene with novel half-sandwich iridium(III) complexes bearing hydroxyindanimine ligands. Chem. Commun. 2008, 3178-3180. [CrossRef] [PubMed]

16. Huang, R.; He, X.; Chen, Y.; Nie, H.; Zhou, W. Homo- and copolymerization of norbornene and 5-norbornene-2-yl acetate with bis-( $\beta$-ketonaphthylamino)palladium(II) $/ \mathrm{B}\left(\mathrm{C}_{6} \mathrm{~F}_{5}\right)_{3}$ catalytic system. Polym. Adv. Technol. 2012, 23, 483-490. [CrossRef]

17. Carlini, C.; Martinelli, M.; Galletti, A.M.R.; Sbrana, G. Vinyl polymerization of norbornene by bis(nitro-substitutedsalicylaldiminate)nickel(II)/methylaluminoxane catalysts. J. Polym. Sci. Part A Polym. Chem. 2006, 44, 1514-1521. [CrossRef]

18. Wang, H.-Y.; Jin, G.-X. Highly Active Neutral Nickel(II) Complexes Bearing P,N-Chelate Ligands: Synthesis, Characterization and Their Application to Addition Polymerization of Norbornene. Eur. J. Inorg. Chem. 2005, 9, 1665-1670. [CrossRef]

19. Vougioukalakis, G.C.; Stamatopoulos, I.; Petzetakis, N.; Raptopoulou, C.P.; Psycharis, V.; Terzis, A.; Kyritsis, P.; Pitsikalis, M.; Hadjichristidis, N. Controlled vinyl-type polymerization of norbornene with a Nickel(II) diphosphinoamine/methylaluminoxane catalytic system. J. Polym. Sci. A Polym. Chem. 2009, 47, 5241-5250. [CrossRef]

20. Antonov, A.A.; Semikolenova, N.V.; Zakharov, V.A.; Zhang, W.; Wang, Y.; Sun, W.-H.; Talsi, E.P.; Bryliakov, K.P. Vinyl Polymerization of Norbornene on Nickel Complexes with Bis(imino)pyridine Ligands Containing Electron-Withdrawing Groups. Organometallics 2012, 31, 1143-1149. [CrossRef]

21. Du, J.; Li, L.-J.; Li, Y. Ni(II) complexes bearing 2-aryliminobenzimidazole: synthesis, structure and ethylene oligomerization study. Inorg. Chem. Commun. 2005, 8, 246-248. [CrossRef]

22. Shi, X.-C.; Jin, G.-X. Synthesis and Characterization of Nickel(II) and Palladium(II) Complexes based on Tridentate [N-NP] and [N-NS] Ligands and Their Applications in Norbornene Polymerization. Organometallics 2012, 31, 4748-4754. [CrossRef]

23. Johnson, L.K.; Killian, C.M.; Brookhart, M. New Pd(II)- and Ni(II)-Based Catalysts for Polymerization of Ethylene and alpha.-Olefins. J. Am. Chem. Soc. 1995, 117, 6414-6415. [CrossRef]

24. Gates, D.P.; Svejda, S.A.; Onate, E.; Killian, C.M.; Johnson, L.K.; White, P.S.; Brookhart, M. Synthesis of Branched Polyethylene Using ( $\alpha$-Diimine)nickel(II) Catalysts: Influence of Temperature, Ethylene Pressure, and Ligand Structure on Polymer Properties. Macromolecules 2000, 33, 2320-2334. [CrossRef]

25. Guan, Z.; Cotts, P.M.; McCord, E.F.; McLain, S. Chain Walking: A New Strategy to Control Polymer Topology. J. Sci. 1999, 283, 2059-2062. [CrossRef]

26. Killian, C.M.; Tempel, D.J.; Johnson, L.K.; Brookhart, M. Living Polymerization of $\alpha$-Olefins Using $\mathrm{Ni}^{\mathrm{II}}-\alpha$-Diimine Catalysts. Synthesis of New Block Polymers Based on $\alpha$-Olefins. J. Am. Chem. Soc. 1996, 118, 11664-11665. [CrossRef]

27. Takei, I.; Nishibayashi, Y.; Arikawa, Y.; Uemura, S.; Hidai, M. Iridium-Catalyzed Asymmetric Hydrosilylation of Imines Using Chiral Oxazolinyl-Phosphine Ligands. Organometallics 1999, 18, 2271-2274. [CrossRef]

28. Yang, H.; Alvarez-Gressier, M.; Lugan, N.; Mathieu, R. Ruthenium(II) Complexes Containing Optically Active Hemilabile P, N,O-Tridentate Ligands. Synthesis and Evaluation in Catalytic Asymmetric Transfer Hydrogenation of Acetophenone by Propan-2-ol. Organometallics 1997, 16, 1401-1409. [CrossRef]

29. Yang, H.; Lugan, N.; Mathieu, R. Study of the Bonding Properties of the New Ligands $\mathrm{C}_{5} \mathrm{H}_{3} \mathrm{~N}(2-\mathrm{R})$ (6- $\mathrm{CH}_{2} \mathrm{PPhR}$ ) toward Rhodium(I). Evidence for a Dynamic Competition for Bonding between O- and $\mathrm{N}$-Donor Centers When $\mathrm{R}$ = o-Anisyl, $\mathrm{R}=$ Me. Organometallics 1997, 16, 2089-2095. [CrossRef]

30. Kajimoto, T.; Tsuji, J. Preparation of benzenetetracarboxylic acids by the cobalt-catalyzed carbonylation of Schiff bases from benzene dicarbaldehydes and subsequent oxidation. J. Org. Chem. 1983, 48, 1685-1690. [CrossRef]

31. Julija, M.-S.; Marijana, V.; Draen, V.-T. NMR Spectroscopy of 2-Hydroxy-1-naphthylidene Schiff Bases with Chloro and Hydroxy Substituted Aniline Moiety. Croat. Chem. Acta 2006, 79, 489-495.

32. Fasina, T.M.; Dada, R.O. Substituent effect on electronic absorption and biological properties of Schiff bases derived from aniline. J. Chem. Pharm. Res. 2013, 5, 177-181.

33. Lacroix, P.G.; Bella, S.D.; Ledoux, I. Synthesis and Second-Order Nonlinear Optical Properties of New Copper(II), Nickel(II), and Zinc(II) Schiff-Base Complexes. Toward a Role of Inorganic Chromophores for Second Harmonic Generation. Chem. Mater. 1996, 8, 541-545. [CrossRef] 
34. Kermagoret, A.; Braunstein, P. Mono- and Dinuclear Nickel Complexes with Phosphino-, Phosphinito-, and Phosphonitopyridine Ligands: Synthesis, Structures, and Catalytic Oligomerization of Ethylene. Organometallics 2007, 27, 88-99. [CrossRef]

35. Martin, E.M.; Bereman, R.D. Synthesis and characterization of square planar and pseudo-tetrahedral $\mathrm{M}(\mathrm{II}) \mathrm{N}_{2} \mathrm{~S}_{2}$. Inorg. Chim. Acta 1991, 188, 221-231.

36. Deb, T.; Anderson, C.M.; Chattopadhyay, S.; Ma, H.; Young, V.G., Jr.; Jensen, M.P. Steric and electronic effects on arylthiolate coordination in the pseudotetrahedral complexes $\left[\left(\mathrm{Tp}^{\mathrm{Ph}, \mathrm{Me}}\right) \mathrm{Ni}-\mathrm{SAr}\right]\left(\mathrm{Tp} \mathrm{Ph}^{\mathrm{Me}}=\right.$ hydrotris\{3-phenyl -5-methyl-1-pyrazolyl\}borate). Dalton Trans. 2014, 43, 17489-17499. [CrossRef] [PubMed]

37. Yuan, J.; Wang, F.; Yuan, B.; Jia, Z.; Song, F.; Li, J. Highly active ortho-phenyl substituted $\alpha$-diimine Nickel(II) catalysts for "chain walking polymerization" of ethylene: Synthesis of the nanosized dendritic polyethylene. J. Mol. Catal. A Chem. 2013, 370, 132-139. [CrossRef]

38. Hu, P.; Yao, Z.-J; Wang, J.-Q.; Jin, G.-X. Synthesis, Structure, and Olefin Polymerization Behavior of Nickel Complexes with Carborane [S,C] or [S,S] Ligands. Organometallics 2011, 30, 4935-4940. [CrossRef]

39. Yao, Z.-J.; Jin, G.-X. Transition metal complexes based on carboranyl ligands containing N, P, and S donors: Synthesis, reactivity and applications. Coord. Chem. Rev. 2013, 257, 2522-2535. [CrossRef]

40. Kennedy, J.P.; Makowski, H.S.J. Carbonium ion polymerization of norbornene and its derivatives. J. Macromol. Sci. Chem. 1967, A1, 345. [CrossRef]

41. Barnes, D.A.; Benedikt, G.M.; Goodall, B.L.; Hung, S.S.; Kalamarides, H.A.; Lenhard, S.; McIntosh, L.H.; Selvy, K.T.; Shick, R.A.; Rhodes, L.F. Addition Polymerization of Norbornene-Type Monomers Using Neutral Nickel Complexes Containing Fluorinated Aryl Ligands. Macromolecules 2003, 36, 2623-2632. [CrossRef]

42. Patil, A.O.; Zushma, S.; Stibrany, R.T.; Rucker, S.P.; Wheeler, L.M. Vinyl-type polymerization of norbornene by nickel(II) bisbenzimidazole catalysts. J. Polym. Sci. Part A: Polym. Chem. 2003, 41, 2095-2106. [CrossRef]

43. Zhao, C.; Ribeiro, M.R.; de Pinho, M.N.; Subrahmanyam, V.S.; Gil, C.L.; de Lima, A.P. Structural characteristics and gas permeation properties of polynorbornenes with retained bicyclic structure. Polymer 2001, 42, 2455-2462. [CrossRef]

44. Haselwander, T.F.A.; Heitz, W.; Maskos, M. Vinylic polymerization of norbornene by Pd(II)-catalysis in the presence of ethylene. Macromol. Rapid. Commun. 1997, 18, 689-697. [CrossRef]

45. Sheldrick, G.M. SHELXL-97, Program for the Refinement of Crystal Structures; Universität Gtötingen: Goettingen, Germany, 1997.

46. Sheldrick, G.M. SADABS (2.01), Bruker/Siemens Area Detector Absorption Correction Program; Bruker AXS: Madison, WI, USA, 1998.

(C) 2017 by the authors. Licensee MDPI, Basel, Switzerland. This article is an open access article distributed under the terms and conditions of the Creative Commons Attribution (CC BY) license (http:/ / creativecommons.org/licenses/by/4.0/). 